\title{
PENGARUH MODEL PROBLEM BASED LEARNING BERBANTUAN MEDIA GAMBAR BERSERI TERHADAP KETERAMPILAN MENULIS TEKS EKSPLANASI SISWA KELAS VIII SMP NEGERI 12 PADANG
}

\author{
Oleh: \\ Amirah Hizati ${ }^{1}$, Syahrul2 ${ }^{2}$, Ermawati Arief ${ }^{3}$ \\ Program Studi Pendidikan Bahasa dan Sastra Indonesia \\ FBS Universitas Negeri Padang \\ Email: hizatiamirah@gmail.com
}

\begin{abstract}
The purpose of this study were (1) to describe the skills of wrting the text of the explanation of the students of class VIII SMP Negeri 12 Padang before using the serial image media aided problem based learning model, (2) to describe the skills of writing the text of the explanation of class VIII students of SMP Negeri 12 Padang after using problem based learning model serial image media, (3) to analyze the effect of serial image media aided problem based learning model to the writing skills skill of class VIII SMP Negeri 12 Padang. Based on data analysis, the use of serial image media-aided problem based learning model influences the writing skills skill of class VIII students of SMP Negeri 12 Padang.
\end{abstract}

Kata kunci: pengaruh, problem based learning, media gambar berseri, menulis teks

\section{A. Pendahuluan} eksplanasi

Pembelajaran bahasa Indonesia berdasarkan kurikulum 2013 adalah pembelajaran yang berbasis teks. Artinya, pembelajaran bahasa Indonesia tidak keluar dari teks. Pada kelas VIII terdapat delapan teks yang harus dipelajari siswa selama satu tahun, yang dimulai dari teks berita, iklan, eksposisi, puisi, eksplanasi, ulasan, persuasif, dan drama. Semua pembelajaran tersebut didasarkan pada tema dan sub tema. Teks berita, iklan, eksposisi, dan puisi dipelajari pada semester 1, sedangkan teks eksplanasi, ulasan, persuasif, dan drama dipelajari pada semester 2. Dari semua teks tersebut dapat diketahui bahwa akhir dari pembelajaran tentang teks adalah siswa mampu memproduksi/menulis teks. Salah satu keterampilan menulis yang harus dikuasai siswa adalah keterampilan menulis teks eksplanasi.

Kosasih (2017:129) menjelaskan pengertian teks eksplanasi adalah teks yang menerangkan atau menjelaskan mengenai proses atau fenomena alam maupun sosial. Menurut Priyatni (dalam Novita, dkk 2016:162), teks eksplanasi merupakan teks yang berisi penjelasan tentang proses yang berhubungan dengan fenomena alam, sosial, ilmu budaya, dan yang lainnya. Sejalan dengan pendapat tersebut Restuti (dalam Novita, dkk 2016:162), mengungkapkan bahwa teks eksplanasi merupakan teks yang menerangkan atau menjelaskan mengenai proses atau fenomena alam dan sosial.

Menurut Saleh (2016), kemampuan menulis teks eksplanasi dengan menggunakan model STAD terbukti meningkat. Hal ini ditunjukkan pada siklus I sebanyak (52\%) tuntas belajar dan (48\%) siswa belum tuntas belajar. Kemudian setelah dilakukan tindakan pada siklus

\footnotetext{
1 Mahasiswa penulis skripsi Prodi Pendidikan Bahasa dan Sastra Indonesia

2 Pembimbing I, dosen Fakultas Bahasa dan Seni Universitas Negeri Padang

3 Pembimbing II, dosen Fakultas Bahasa dan Seni Universitas Negeri Padang
} 
II diperoleh hasil belajar sebanyak (95\%) tuntas belajar dan (5\%) belum tuntas belajar. Pengajaran menulis teks eksplanasi menggunakan model STAD ini lebih efektif daripada cara konvensional.

Selanjutnya, menurut Novita, Saddhono, Mujyanto (2016), berdasarkan hasil penelitian peningkatan kemampuan menulis teks eksplanasi dengan menggunakan media audiovisual pada siswa sekolah menengah pertama, menunjukkan adanya peningkatan kemampuan menulis teks eksplanasi pada siswa. Rata-rata skor teks eksplanasi siswa adalah 74,61 dengan keberhasilan $69,23 \%$. Pada periode penjelasan tes akhir rata-rata skor siswa adalah 84,42 dengan tingkat keberhasilan $88,46 \%$.

Kumar dan Refaei (2017) menyatakan temuan awal mereka bahwa pemikiran kritis siswa tentang penulisan meningkat dengan penggunaan pedagogi problem based learning. Selanjutnya Wijnen, Loyens, Smeets, Kroeze, Molen (2017) menyatakan untuk mengetahui tingkat keberhasilan problem based learning, para siswa dan guru ditanya tentang pengalaman mereka dan persepsi tentang program problem based learning. Baik siswa dan guru melaporkan perilaku belajar positif, seperti biasa belajar dan keterlibatan aktif siswa sebagai hasil problem based learning. Selanjutnya Strobel dan Barneveld (2009) menyatakan temuan mereka bahwa model problem based learning lebih unggul dalam hal retensi jangka panjang, pengembangan keterampilan dan kepuasan siswa dan guru, sementara pendekatan tradisional lebih efektif untuk retensi jangka pendek yang diukur dengan ujian dewan standar.

Berdasarkan hasil wawancara dengan salah seorang guru bahasa Indonesia SMP Negeri 12 Padang yaitu H. Amril, S.Pd., yang dilaksanakan pada tanggal 10 Januari 2018, penulis menemukan beberapa kendala. Kendala yang dirasakan siswa tersebut adalah sebagai berikut: (1) peserta didik tidak mampu mengungkapkan ide, (2) peserta didik sulit menyusun urutan informasi secara urut dan logis, dan (3) kurangnya motivasi siswa dalam menulis. Berdasarkan kendala yang dirasakan siswa tersebut, penulis tertarik melakukan penelitian menggunakan model problem based learning berbantuan media gambar berseri.

Arends (dalam Kurnia, 2015:75) mengemukakan problem based learning adalah pembelajaran yang menyuguhkan berbagai situasi masalah yang autentik dan bermakna kepada siswa, yang dapat berfungsi sebagai batu loncatan untuk investigasi dan penyelidikan. Secara lebih luas, menurut Tan (dalam Kurnia, 2015:75), pembelajaran berbasis masalah merupakan inovasi dalam pembelajaran karena dalam PBM kemampuan berpikir siswa dapat memberdayakan, mengasah, menguji, dan mengembangkan kemampuan berpikirnya secara berkesinambungan.

Pembelajaran dengan model problem based learning dimulai oleh adanya masalah yang dalam hal ini dapat dimunculkan oleh siswa maupun guru, kemudian siswa memperdalam pengetahuannya tentang apa yang mereka telah ketahui atau apa yang perlu mereka ketahui untuk memecahkan masalah tersebut. Siswa dapat memilih masalah yang dianggap menarik untuk dipecahkan sehingga mereka terdorong berperan aktif dalam kegiatan belajar.

Media gambar berseri adalah media yang digunakan dalam pembelajaran berbentuk visual memberikan rangkaian gambar tentang sesuatu sehingga penjelasannya lebih konkrit daripada diuraikan lewat kata-kata. Melalui gambar berseri, guru dapat menerjemahkan ide-ide abstrak yang lebih realistik dan semakin mudah untuk merangsang daya imajinasi siswa.

Tujuan penelitian ini untuk mendeskripsikan hal-hal sebagai berikut. Pertama, mendeskripsikan keterampilan menulis teks eksplanasi siswa kelas VIII SMP Negeri 12 Padang sebelum menggunakan model problem based learning berbantuan media gambar berseri. Kedua, mendeskripsikan keterampilan menulis teks eksplanasi siswa kelas VIII SMP Negeri 12 Padang sesudah menggunakan model problem based learning berbantuan media gambar berseri. Ketiga, menganalisis pengaruh model problem based learning berbantuan media gambar berseri terhadap keterampilan menulis teks eksplanasi siswa kelas VIII SMP Negeri 12 Padang. 
Pengaruh Model Problem Based Learning Berbantuan Media Gambar Berseri terhadap Keterampilan Menulis Teks Eksplanasi Siswa Kelas VIII SMP Negeri 12 Padang- Amirah Hizati, Syahrul R., dan Ermawati Arief.

\section{B. Metode Penelitian}

Jenis penelitian ini adalah penelitian kuantitatif. Penelitian ini dikatakan penelitian kuanitatif dikarenakan data penelitian ini berupa angka. Arikunto (2014:27) mengemukakan bahwa penelitian kuantitatif merupakan penelitian yang menggunakan angka dimulai dari pengumpulan data, kemudian menafsirkan data dan terakhir hasilnya. Data penelitian yang diolah berupa angka-angka yang diperoleh dari skor hasil tes keterampilan menulis teks eksplanasi siswa kelas VIII SMP Negeri 12 Padang.

Metode penelitian yang digunakan dalam penelitian ini adalah metode eksperimen. Hal ini sesuai dengan pendapat Arifin (2012:42), metode eksperimen merupakan metode yang sistematis guna membangun hubungan yang mengandung fenomena sebab-akibat. Dalam metode eksperimen peneliti harus melakukan tiga kegiatan sekaligus, yaitu mengontrol, memanipulasi, dan mengobservasi.

Jenis eksperimen ini adalah quasi eksperimen (eksperimen semu) karena eksperimen ini belum atau tidak memiliki ciri-ciri rancangan eksperimen yang sebenarnya. Oleh sebab itu, validitas penelitian menjadi kurang cukup untuk disebut sebagai eksperimen yang sebenarnya. Menurut Suryabrata (2012:92), eksperimen semu bertujuan untuk memperoleh informasi yang merupakan perkiraan bagi informasi yang dapat diperoleh dengan eksperimen yang sebenarnya dalam keadaan yang tidak memungkinkan untuk mengontrol dan memanipulasi semua variabel yang relevan.

Rancangan penelitian yang digunakan dalam penelitian ini adalah the one group pretesposttest design. Rancangan penelitian ini merupakan rancangan yang menggunakan satu kelompok/subjek. Pernyataan ini sesuai dengan pendapat Suryabrata (2012:101) yang mengungkapkan bahwa dalam rancangan penelitian the one group pretes-posttest design digunakan satu kelompok subjek. Pertama-tama dilakukan pengukuran, lalu dikenakan perlakuan jangka waktu tertentu, kemudian dilakukan pengukuran untuk kedua kalinya.

Menurut Sugiyono (2010:80) populasi adalah wilayah generalisasi yang terdiri atas objek atau subjek yang mempunyai kualitas dan karakteristik tertentu yang ditetapkan oleh peneliti untuk dipelajari dan kemudian ditarik kesimpulannya. Populasi dalam penelitian ini adalah seluruh siswa kelas VIII SMP Negeri 12 Padang yang terdaftar pada tahun pelajaran 2017/2018 yang berjumlah 264 orang yang tersebar dalam delapan kelas, yaitu kelas VIII-1, VIII-2. VIII-3. VIII-4, VIII-5, VIII-6, VIII-7, dan VIII-8. Sampel adalah bagian dari jumlah dan karakteristik yang dimiliki oleh populasi (Sugiyono, 2010:80). Penarikan sampel dilakukan dengan teknik purposive sampling. Arikunto (2014:183) menyatakan bahwa pengambilan sampel secara purposive sampling dilakukan dengan cara mengambil subjek bukan didasarkan atas strata, random, atau daerah tetapi didasarkan atas tujuan dan syarat tertentu yang harus dipenuhi, yaitu didasarkan pada ciri pokok populasi, subjek yang diambil paling banyak mengandung ciri populasi, dan dilakukan studi pendahuluan. Sampel dalam penelitian ini diambil berdasarkan rata-rata dan standar deviasi kelas pada pelajaran Bahasa Indonesia yaitu kelas VIII-2

Menurut Arikunto (2014:161) variabel adalah objek penelitian, atau apa yang menjadi titik perhatian suatu penelitian. Pada penelitian ini terdapat dua variabel, yaitu keterampilan menulis teks eksplanasi siswa kelas VIII SMP Negeri 12 Padang sebelum menggunakan model problem based learning berbantuan media gambar berseri dan keterampilan menulis teks eksplanasi siswa kelas VIII SMP Negeri 12 Padang sesudah menggunakan model problem based learning berbantuan media gambar berseri. Data penelitian ini diperoleh dari skor hasil tes unjuk kerja yang dilakukan.

Instrumen yang digunakan dalam penelitian ini adalah tes unjuk kerja, yaitu tes keterampilan menulis teks eksplanasi. Sebelum instrumen diujicobakan, langkah awal yang dilakukan adalah memvalidasi oleh dosen pembimbing yang mengerti dalam bidang evaluasi pembelajaran serta guru mata pelajaran Bahasa Indonesia kelas VIII SMP Negeri 12 Padang, yaitu H. Amril, S.Pd. selain mendiskusikan instrumen dengan ahlinya, validitas isi instrumen juga dilakukan dengan menyelaraskan instrumen dengan indikator yang digunakan. 


\section{Pembahasan}

Pada bagian ini dibahas mengenai hasil keterampilan menulis teks eksplanasi siswa kelas VIII SMP Negeri 12 Padang sebelum dan sesudah menggunakan model problem based learning berbantuan media gambar berseri. Pertama, keterampilan menulis teks eksplanasi sebelum menggunakan model problem based learning berbantuan media gambar berseri. Kedua, keterampilan menulis teks eksplanasi sesudah menggunakan model problem based learning berbantuan media gambar berseri. Ketiga, pengaruh model problem based learning berbantuan media gambar berseri terhadap keterampilan menulis teks eksplanasi siswa kelas VIII SMP Negeri 12 Padang.

\section{Keterampilan Menulis Teks Eksplanasi Siswa Kelas VIII SMP Negeri 12 Padang Sebelum Menggunakan Model Problem Based Learning Berbantuan Media Gambar Berseri}

Berdasarkan analisis data diperoleh rata-rata hitung tes keterampilan menulis teks eksplanasi siswa kelas VIII SMP Negeri 12 Padang sebelum menggunakan model problem based learning berbantuan media gambar berseri (pretest) sebesar 69,62. Dari rata-rata hitung tersebut dapat disimpulkan bahwa pretest keterampilan menulis teks eksplanasi berkualifikasi Lebih dari Cukup (LdC). Selain menggunakan rata-rata hitung (M) sebagai tolak ukur, maka untuk menentukan pretest keterampilan menulis teks eksplanasi dapat menggunakan KKM. KKM yang ditetapkan untuk mata pelajaran Bahasa Indonesia di SMP Negeri 12 Padang adalah 75. Oleh karena itu, pretest keterampilan menulis teks eksplanasi lebih rendah dari KKM yang ditetapkan oleh sekolah.

Pretest keterampilan menulis teks eksplanasi dapat dilakukan dengan analisis per indikator. Adapun indikator yang dinilai, sebagai berikut. Pertama, menjelaskan isi teks eksplanasi sesuai dengan topik yang dibahas. Rata-rata hitung pretest keterampilan menulis teks eksplanasi untuk indikator 1 adalah 68,15. Beberapa dari siswa kurang menjelaskan secara logis bagaimana peristiwa itu terjadi, sehingga topik yang dibahas kurang terperinci. Hal tersebut tidak sejalan dengan Sari (2016:3) yang menyatakan teks eksplanasi merupakan jenis teks yang menjelaskan hubungan logis dari beberapa peristiwa.

Terbatasnya pengetahuan siswa untuk memberikan penjelasan juga menjadi alasan dari topik yang dibahas kurang terperinci. Kemudian disebabkan juga oleh siswa yang susah dalam mengungkapkan gagasan ke dalam bentuk tulisan. Siswa juga belum terlatih dalam menulis hal itu dikarenakan keterampilan menulis bagi siswa masih menjadi pelajaran yang sulit. Dalam indikator 1, masih banyak siswa yang menulis teks eksplanasi yang kurang sesuai dengan topik yang dibahas dan penjelasannya juga kurang terperinci.

Kedua, memuat tiga bagian struktur teks eksplanasi secara urut dan logis. Rata-rata hitung pretest keterampilan menulis teks eksplanasi untuk indikator 2 adalah 70,16. Siswa lebih banyak mengungkapkan hanya penjelasan dari topik yang dibahas atau siswa hanya menuliskan rangkaian kejadian dari topik yang dibahas. Hal itu tidak sejalan dengan Kosasih (2017:138) yang menyatakan ada tiga bagian struktur teks eksplanasi, yaitu (a) identifikasi fenomena, (b) rangkaian kejadian, dan (c) ulasan. Identifikasi fenomena adalah mengidentifikasi sesuatu yang akan dijelaskan. Rangkaian kejadian adalah perincian atas kejadian yang relevan dengan identifikasi fenomena. Ulasan adalah komentar atau penilaian tentang kejadian yang sudah dijelaskan.

Penulisan struktur teks eksplanasi juga masih kurang urut dan kurang logis. Siswa juga masih tampak bingung dalam menyusun urutan dari struktur teks eksplanasi sesuai dengan topik yang dibahas. Hal tersebut disebabkan karena masih banyak siswa yang tidak memperhatikan urutan yang benar dari struktur teks eksplanasi. Dalam indikator 2 tersebut banyak teks eksplanasi yang ditulis siswa tidak terstruktur sehingga teks eksplanasi yang ditulis siswa kurang terperinci.

Ketiga, penggunaan empat ciri kebahasaan. Rata-rata hitung pretest keterampilan menulis teks eksplanasi untuk indikator 3 adalah 70,56. Kebanyakan dari siswa hanya 
Pengaruh Model Problem Based Learning Berbantuan Media Gambar Berseri terhadap Keterampilan Menulis Teks Eksplanasi Siswa Kelas VIII SMP Negeri 12 Padang- Amirah Hizati, Syahrul R., dan Ermawati Arief.

menuliskan satu atau dua dari empat ciri kebahasaan teks eksplanasi. Hal itu tidak sejalan dengan Kosasih (2017:144) yang menyatakan ada empat ciri kebahasaan yang terdapat di dalam teks eksplanasi, yaitu (a) konjungsi kausalitas, (b) konjungsi kronologis, (c) benda, dan (d) istilah.

Hal tersebut disebabkan karena banyak dari siswa yang tidak mengetahui pentingnya ciri kebahasaan teks eksplanasi. Ciri kebahasaan teks eksplanasi berfungsi untuk membedakannya dengan teks lain, hal itu karena teks eksplanasi memiliki ciri kebahasaan yang relatif berbeda dengan teks lain. Penyebab lainnya adalah siswa kurang menguasai dan kurang memperhatikan ciri kebahasaan ketika menulis teks eksplanasi. Dalam indikator 3, ciri kebahasaan yang terdapat dalam teks eksplanasi yang ditulis siswa masih kurang.

\section{Keterampilan Menulis Teks Eksplanasi Siswa Kelas VIII SMP Negeri 12 Padang Sesudah Menggunakan Model Problem Based Learning Berbantuan Media Gambar Berseri}

Berdasarkan analisis data diperoleh rata-rata hitung keterampilan menulis teks eksplanasi siswa kelas VIII SMP Negeri 12 Padang sesudah menggunakan model problem based learning berbantuan media gambar berseri (postest) sebesar 84,27. Dari rata-rata hitung tersebut dapat disimpulkan bahwa postest keterampilan menulis teks eksplanasi berkualifikasi Baik (B). Selain menggunakan rata-rata hitung (M) sebagai tolak ukur, maka untuk menentukan postest keterampilan menulis teks eksplanasi juga dapat menggunakan KKM. KKM yang ditetapkan untuk mata pelajaran Bahasa Indonesia di SMP Negeri 12 Padang adalah 75. Oleh karena itu, postest keterampilan menulis teks eksplanasi lebih tinggi dari KKM yang ditetapkan oleh sekolah.

Postest keterampilan menulis teks eksplanasi dapat dilakukan dengan analisis per indikator. Adapun indikator yang dinilai yaitu sebagai berikut. Pertama, menjelaskan isi teks eksplanasi sesuai dengan topik yang dibahas. Rata-rata hitung postest keterampilan menulis teks eksplanasi untuk indikator 1 adalah 82,26. Dibandingkan dengan hasil pretest keterampilan menulis teks eksplanasi, hasil postest keterampilan menulis teks eksplanasi lebih tinggi dari hasil pretest keterampilan menulis teks eksplanasi. Hal itu disebabkan dalam pembelajaran menulis teks eksplanasi, siswa sebelumnya diberi latihan menulis teks eksplanasi dengan bantuan media gambar berseri. Siswa juga diberi kesempatan untuk berdiskusi dengan kelompok kecil (teman sebangku) untuk menjelaskan isi yang sesuai dengan gambar berseri yang sudah disediakan. Dengan demikian, siswa sudah mengerti cara menjelaskan sesuatu dengan berbantuan media gambar berseri.

Teks eksplanasi yang ditulis siswa juga sudah sesuai dengan topik yang dibahas. Selain itu, penjelasan yang dijelaskan tentang bagaimana peristiwa itu terjadi sudah cukup logis dan terperinci. Hal itu sejalan dengan Sari (2016:3) yang menyatakan teks eksplanasi merupakan jenis teks yang menjelaskan hubungan logis dari beberapa peristiwa. Dalam indikator 1, teks eksplanasi siswa sudah cukup sesuai dengan topik yang dibahas dan cukup terperinci.

Kedua, memuat tiga bagian struktur teks eksplanasi secara urut dan logis. Rata-rata hitung postest keterampilan menulis teks eksplanasi untuk indikator 2 adalah 94,35. Dibandingkan dengan hasil pretest keterampilan menulis teks eksplanasi, hasil postest keterampilan menulis teks eksplanasi jauh lebih tinggi dari hasil pretest keterampilan menulis teks eksplanasi. Jika dilihat dari postest keterampilan menulis teks eksplanasi terlihat siswa sudah mampu menulis teks eksplanasi dengan memperhatikan tiga bagian struktur secara urut dan logis. Hal itu sejalan dengan Kosasih (2017:138) yang menyatakan ada tiga bagian struktur teks eksplanasi, yaitu (a) identifikasi fenomena, (b) rangkaian kejadian, dan (c) ulasan. Identifikasi fenomena adalah mengidentifikasi sesuatu yang akan dijelaskan. Rangkaian kejadian adalah perincian atas kejadian yang relevan dengan identifikasi fenomena. Ulasan adalah komentar atau penilaian tentang kejadian yang sudah dijelaskan.

Penulisan struktur teks eksplanasi yang ditulis siswa sudah urut dan logis. Siswa juga sudah paham dalam menyusun urutan dari struktur teks eksplanasi sesuai dengan topik yang 
dibahas. Selain itu, siswa juga sudah paham dalam memperhatikan urutan yang benar dari struktur teks eksplanasi. Dalam indikator 2 tersebut banyak teks eksplanasi yang ditulis siswa sudah terstruktur secara urut dan logis.

Ketiga, penggunaan empat ciri kebahasaan. Rata-rata hitung postest keterampilan menulis teks eksplanasi untuk indikator 3 adalah 76,21. Dibandingkan dengan hasil pretest keterampilan menulis teks eksplanasi, hasil postest keterampilan menulis teks eksplanasi lebih tinggi dari hasil pretest keterampilan menulis teks eksplanasi. Kebanyakan dari siswa sudah mampu menggunakan tiga ciri kebahasaan teks eksplanasi. Hal itu sejalan dengan Kosasih (2017:144) yang menyatakan ada empat ciri kebahasaan yang terdapat di dalam teks eksplanasi, yaitu (a) konjungsi kausalitas, (b) konjungsi kronologis, (c) benda, dan (d) istilah.

Hal tersebut disebabkan pada saat latihan menulis teks eksplanasi dengan kelompok siswa memperhatikan ciri kebahasaan beserta contohnya. Selain itu, siswa juga sudah mengetahui pentingnya ciri kebahasaan teks eksplanasi yang bertujuan untuk membedakannya dengan teks lain. Hal itulah yang menyebabkan peningkatan dalam penggunaan ciri kebahasaan dalam tulisan teks eksplanasi siswa. Dalam indikator 3, teks eksplanasi yang ditulis siswa sudah memuat ciri kebahasaan yang terdapat dalam teks eksplanasi.

\section{Pengaruh Penggunaan Model Problem Based Learning Berbantuan Media Gambar Berseri terhadap Keterampilan Menulis Teks Eksplanasi Siswa Kelas VIII SMP Negeri 12 Padang}

Model problem based learning berbantuan media gambar berseri baik untuk diterapkan dalam pembelajaran menulis teks eksplanasi. Hal itu terlihat dari hasil tes keterampilan menulis teks eksplanasi siswa kelas VIII SMP Negeri 12 Padang sesudah menggunakan model problem based learning berbantuan media gambar berseri lebih tinggi dibandingkan dengan hasil tes keterampilan menulis teks eksplanasi siswa kelas VIII SMP Negeri 12 Padang sebelum menggunakan model problem based learning berbantuan media gambar berseri. Siswa terlihat lebih antusias dan bersemangat dalam proses pembelajaran dengan menggunakan model problem based learning berbantuan media gambar berseri. Hal tersebut sejalan dengan pendapat Trianto (2012:96) ada lima kelebihan model problem based learning. Pertama, realistis dengan kehidupan siswa. Kedua, konsep sesuai dengan kebutuhan siswa. Ketiga, memupuk sifat inquiry. Keempat, retensi konsep jadi kuat. Kelima, memupuk kemampuan problem solving.

Kemampuan problem solving yang terbentuk dari problem based learning juga berdampak bagus bagi siswa yaitu. Pertama, pemecahan masalah cukup bagus untuk lebih memahami isi pelajaran. Kedua, pemecahan masalah dapat menantang kemampuan peserta didik serta memberikan kepuasan untuk menentukan pengetahuan baru bagi peserta didik. Ketiga, pemecahan masalah dapat meningkatkan aktivitas pembelajaran peserta didik. Keempat, pemecahan masalah dapat membantu peserta didik bagaimana mentransfer pengetahuan mereka untuk memahami masalah dalam kehidupan nyata. Kelima, pemecahan masalah dapat membantu peserta didik untuk mengembangkan pengetahuan barunya dan bertanggung jawab dalam pembelajaran yang mereka lakukan. Keenam, melalui pemecahan masalah dianggap lebih menyenangkan dan disukai peserta didik. Ketujuh, pemecahan masalah dapat mengembangkan kemampuan peserta didik untuk berpikir kritis dan mengembangkan kemampuan mereka untuk menyesuaikan dengan pengetahuan baru. Kedelapan, pemecahan masalah dapat memberikan kesempatan pada peserta didik untuk mengaplikasikan pengetahuan yang mereka miliki dalam dunia nyata. Kesembilan, pemecahan masalah dapat mengembangkan minat peserta didik untuk secara terus-menerus belajar.

Dari uraian di atas dapat disimpulkan bahwa model problem based learning harus dimulai dengan kesadaran adanya masalah yang harus dipecahkan. Pada tahapan ini guru membimbing peserta didik pada kesadaran adanya kesenjangan atau apa yang dirasakan oleh manusia atau lingkungan sosial. Kemampuan yang harus dicapai oleh peserta didik, pada tahapan ini adalah peserta didik dapat menentukan atau menangkap kesenjangan yang terjadi dari berbagai fenomena yang ada, khususnya dalam pembelajaran menulis teks eksplanasi. 
Pengaruh Model Problem Based Learning Berbantuan Media Gambar Berseri terhadap Keterampilan Menulis Teks Eksplanasi Siswa Kelas VIII SMP Negeri 12 Padang- Amirah Hizati, Syahrul R., dan Ermawati Arief.

Salah satu upaya tersebut berupa penggunaan model problem based learning berbantuan media gambar berseri dalam pembelajaran keterampilan menulis teks eksplanasi. Selanjutnya, ditinjau dari hasil menulis teks eksplanasi siswa, keterampilan menulis teks eksplanasi siswa sebelum menggunakan model problem based learning berbantuan media gambar berseri lebih rendah dibandingkan dengan hasil menulis teks eksplanasi siswa sesudah menggunakan model problem based learning berbantuan media gambar berseri. Hal itu terbukti dari hasil penelitian yang menunjukkan bahwa keterampilan menulis teks eksplanasi siswa kelas VIII SMP Negeri 12 Padang sebelum menggunakan model problem based learning berbantuan media gambar berseri berada pada kualifikasi Lebih dari Cukup dengan rata-rata 69,62. Sebaliknya, keterampilan menulis teks eksplanasi siswa kelas VIII SMP Negeri 12 Padang sesudah menggunakan model problem based learning berbantuan media gambar berseri berada pada kualifikasi Baik dengan rata-rata $84,27$.

Demikian juga dengan hasil uji hipotesis diperoleh $\mathrm{T}_{\text {hitung }} 4,29$, sedangkan $\mathrm{T}_{\text {tabel }} 1,70$. Jadi, dapat disimpulkan bahwa model problem based learning berbantuan media gambar berseri berpengaruh secara signifikan dengan taraf $95 \%$ karena $\mathrm{T}_{\text {hitung }}>\mathrm{T}_{\text {tabel }}(4,29>1,70)$. Perbedaan rata-rata keterampilan menulis teks eksplanasi siswa sebelum menggunakan model problem based learning berbantuan media gambar berseri dan sesudah menggunakan model problem based learning berbantuan media gambar berseri dianggap sebagai pengaruh yang ditimbulkan oleh penggunaan model problem based learning berbantuan media gambar berseri tersebut. Dengan demikian, penggunaan model problem based learning berbantuan media gambar berseri berpengaruh terhadap keterampilan menulis teks eksplanasi siswa kelas VIII SMP Negeri 12 Padang.

\section{Simpulan dan Saran}

Keterampilan menulis teks eksplanasi siswa kelas VIII SMP Negeri 12 Padang sebelum menggunakan model problem based learning berbantuan media gambar berseri. Pada indikator 1, beberapa dari siswa kurang menjelaskan secara logis bagaimana peristiwa itu terjadi, sehingga topik yang dibahas kurang terperinci. Pada indikator 2, siswa lebih banyak mengungkapkan hanya penjelasan dari topik yang dibahas atau siswa hanya menuliskan rangkaian kejadian dari topik yang dibahas. Pada indikator 3, kebanyakan dari siswa hanya menuliskan satu atau dua dari empat ciri kebahasaan teks eksplanasi.

Keterampilan menulis teks eksplanasi siswa kelas VIII SMP Negeri 12 Padang sesudah menggunakan model problem based learning berbantuan media gambar berseri. Pada indikator 1 , teks eksplanasi yang ditulis siswa juga sudah sesuai dengan topik yang dibahas. Selain itu, penjelasan yang dijelaskan tentang bagaimana peristiwa itu terjadi sudah cukup logis dan terperinci. Pada indikator 2, siswa sudah mampu menulis teks eksplanasi dengan memperhatikan tiga bagian struktur secara urut dan logis. Pada indikator 3, kebanyakan dari siswa sudah mampu menggunakan tiga ciri kebahasaan teks eksplanasi.

Demikian juga dengan hasil uji hipotesis diperoleh $\mathrm{T}_{\text {hitung }} 4,29$, sedangkan $\mathrm{T}_{\text {tabel }} 1,70$. Jadi, dapat disimpulkan bahwa model problem based learning berbantuan media gambar berseri berpengaruh secara signifikan dengan taraf $95 \%$ karena $\mathrm{T}_{\text {hitung }}>\mathrm{T}_{\text {tabel }}(4,29>1,70)$. Dengan demikian, penggunaan model problem based learning berbantuan media gambar berseri berpengaruh terhadap keterampilan menulis teks eksplanasi siswa kelas VIII SMP Negeri 12 Padang.

Berdasarkan simpulan yang diperoleh dari hasil penelitian di atas, maka diajukan saransaran sebagai berikut. Pertama, disarankan kepada guru mata pelajaran Bahasa Indonesia di SMP Negeri 12 Padang agar menerapkan penggunaan model problem based leraning berbantuan media gambar berseri dalam pembelajaran keterampilan menulis teks eksplanasi. Kedua, disarankan kepada siswa kelas VIII SMP Negeri 12 Padang untuk lebih banyak berlatih menulis baik di sekolah maupun di luar sekolah, agar keterampilan dalam menulis teks eksplanasi dapat dikembangkan dengan baik dan menjadi terampil. Ketiga, untuk peneliti, diharapkan untuk dapat mengembangkan lebih lanjut dengan wawasan mengenai penerapan pembelajaran 
menulis inovatif dan mengaplikasikan teori yang telah diperoleh. Keempat, saran untuk peneliti lain diharapkan agar dapat dijadikan sebagai acuan ataupun perbandingan dalam melakukan penelitian yang berkaitan dengan masalah ini.

Catatan: Artikel ini disusun berdasarkan skripsi Amirah Hizati dengan pembimbing I, Prof. Dr. Syahrul R., M.Pd. dan pembimbing II, Dra. Ermawati Arief, M.Pd.

\section{Kepustakaan}

Arifin, Z. (2012). Penelitian Pendidikan.: Metode dan Paradigma Baru. Bandung: Rosda.

Arikunto, S. (2014). Prosedur Penelitian. Jakarta: Rineka Cipta.

Kosasih, E. (2017). Buku Siswa Bahasa Indonesia untuk SMP/MTs Kelas VIII. Jakarta, Pusat Kurikulum dan dan Perbukuan, Balitbang, Kemendikbud.

Kumar, R. dan Brenda, R. (2017). Problem-Based Learning Pedagogy Fosters Students Critical Thinking About Writing. Interdisciplinary Journal of Problem-Based Learning. 11 (2), 1-10.

Kurnia. (2015). Penerapan Model Problem Based Learning untuk Meningkatkan Kemampuan Menulis Teks Eksposisi Pada Siswa Kelas X IIS-4 SMA Negeri 8 Makassar. Jurnal Pepatuzdu. 9 (1), 72-84.

Novita, A, dkk. (2016). Peningkatan Kemampuan Menulis Teks Eksplanasi dengan Menggunakan Media Audiovisual pada Siswa Sekolah Menengah Pertama. Jurnal Penelitian Bahasa, Sastra Indonesia dan Pengajarannya. 4 (2).

Saleh, M. (2016). Peningkatan Kemampuan Menulis Teks Eksplanasi Komplek Melalui Model STAD Pada Siswa SMA. Briliant: Jurnal Riset dan Konseptual. 1 (1)

Sari, A.M dan Nurlaksana, E.R. (2016). Pembelajaran Menyusun Teks Eksplanasi Siswa Kelas VII SMP Negeri 1 Gedong Tataan. Jurnal Kata: Bahasa, Sastra dan Pembelajarannya.

Strobel, J. dan Barneveld, A. V. (2009). When is PBL More Effective? A Meta-synthesis of Metaanalyses Comparing PBL to Conventional Classrooms. Interdisciplinary Journal of Problem-Based Learning. 3(1), 44-58.

Sugiyono. (2010). Metode Penelitian Kuantitatif dan R\&D. Bandung, Alfabeta.

Suryabrata, S. (2012). Metodologi Penelitian. Jakarta: Grafindo Persada.

Trianto. (2012). Mendesain Model Pembelajaran Inovatif-Progresif. Jakarta, Kencana.

Wijnen, M. dkk. (2017). Students and Teachers Experiences With the Implementation of Problem-Based Learning at a University Law School. Interdisciplinary Journal of ProblemBased Learning. 11 (2), 1-11. 